\title{
PENGEMBANGAN MODEL BIMBINGAN KLASIKAL UNTUK MENINGKATAN MOTIVASI BELAJAR SISWA SMP
}

\author{
Muh Farozin \\ FIP Universitas Negeri Yogyakarta (e-mail: farozin2311@yahoo.com)
}

\begin{abstract}
Abstrak: Pengembangan Model Bimbingan Klasikal untuk Meningkatkan Motivasi Belajar Siswa SMP. Penelitian ini bertujuan mengembangkan model bimbingan klasikal untuk meningkatkan motivasi belajar siswa SMP di Kulon Progo Yogyakarta dan mengetahui efektivitas modelnya. Pendekatan penelitian adalah Research and Development dengan subjek penelitian siswa dan guru bimbingan dan konseling. Metode pengumpulan data adalah angket bimbingan klasikal dan inventori motivasi belajar. Analisis data menggunakan uji t dan deskriptif. Bimbingan klasikal dilaksanakan melalui interaksi edukatif, menggunakan metode ceramah, tanya jawab, diskusi, media film, LCD, hand out, papan tulis, terjadwal sepuluh pertemuan, disusun satuan layanan dengan topik delapan faktor instriksik motivasi belajar siswa. Uji efektivitas model menggunakan pretest dan posttest motivasi belajar siswa. Secara keluruhan, hasil penelitian menunjukkan bahwa bimbingan klasikal efektif digunakan untuk meningkatkan motivasi belajar siswa SMP di Kulon Progo dengan kontribusi peningkatan 44,99\%.
\end{abstract}

Kata Kunci: bimbingan klasikal, motivasi belajar

\begin{abstract}
Developing Model of Classroom Guidance to Improve Learning Motivation of Junior High School Students. This study aims at developing model of classroom guidance for improving learning motivation and measuring its effectiveness in increasing learning motivation of students of Junior High Schools in Kulon Progro, Yogyakarta. The study is Research and Development. The subjects involve students and Guidance and Counseling teachers. The data were collected using questionnaires of classroom guidance and an inventory of learning motivation, and analyzed descriptively and through T-test. The classroom guidance was conducted through educative interaction, delivered through lectures comprising question - answer and discussion. The guidance utilized film media, LCD, handout and whiteboard. It was scheduled for 10 sessions, within 8 units of classroom guidance services. The model was examined for its effectiveness using pretest and posttest of learning motivation. Overall, the finding shows that the classroom guidance is effective in improving learning motivation of students of Junior High Schools in Kulon Progo Yogyakarta with $44.99 \%$ rise.
\end{abstract}

Keywords: classroom guidance, learning motivation 


\section{PENDAHULUAN}

Siswa sebagaimakhlukindividu dan sosial tidak dapat dipisahkan, bersifat unik dan dinamis dalam kehidupan sehari-hari, memiliki perbedaan antara siswa satu dengan lain, memiliki potensi untuk tumbuh dan berkembang sesuai situasi dan kondisi serta pengalaman belajar yang diperolehnya, mempunyai tujuan belajar dan ingin mencapai hasilbelajar yang maksimal, mempunyai keterbatasan diri sehingga perlu memperoleh bantuan. Hasil belajar siswa diharapkan sebagaimana tujuan pendidikan, yaitu terbentuknya manusia yang beriman dan bertaqwa kepada Tuhan Yang Maha Esa, berakhlak mulia, sehat, berilmu, cakap, kreatif, mandiri, dan menjadi warga negara yang demokratis serta bertanggung jawab (UU Sisdiknas No. 20 Tahun 2003). Schunk \& Pajares (2005; Harpine: 2008) mengemukakan bahwa individu merupakan produk atau hasil dari suatu lingkungan, tetapi mereka juga menciptakan dan menginterpretasikan pengalaman lingkungan mereka dengan cara belajar. Seorang individu pada hakikatnya memiliki hasrat pribadi untuk belajar (Sternberg, 2000; Harpine: 2008). Santrock dan Yussen (1994) mengemukakan bahwa belajar merupakan sebuah perubahan yang relatif bersifat permanen karena adanya pengalaman, dan dalam proses belajar ada perubahan yang menetap pada diri seseorang berkaitan aspek kognitif, afektif, psikomotorik, dan konasi. Perubahan perilaku akibat belajar dapat bersifat positif, fungsional, bertujuan, dan melibatkan seluruh aspek perilaku.
Proses dan hasil belajar siswa terdapat banyak faktor yang mempengaruhinya antara lain minat melajar, motivasi belajar, bakat, metode dan alat belajar, kondisi lingkungan belajar, perhatian orang tua, fasilitiasi guru, dan teman pergaulan. Muhibbinsyah (1997) mengemukakan 3 macam faktor-faktor yang mempengaruhi belajar, yaitu faktor internal, eksternal dan pendekatan belajar. Faktor-faktor tersebut berpengaruh terhadap proses dan pencapaian hasil belajar. Siswa yang memiliki motivasi belajarnya tinggi, maka tanpa disuruhpun siswa akan belajar secara giatdan sungguh-sungguh. Dalam kaitannya dengan prestasi belajar, hasil penelitian Tukija (2006) menunjukkan bahwa terdapat hubungan yang positif dan signifikan antara motivasi belajar dengan prestasi belajar, dalam arti bahwa siswa yang memiliki motivasi belajar tinggi akan cenderung dapat memiliki hasil belajar yang tinggi pula. Ibrahim (1996:27-29) menyatakan bahwa dalam kegiatan belajar diperlukan unsur motivasi, dan motivasi adalah suatu proses kontinyu dimana seseorang mempertahankan perhatian untuk keberhasilan dalam kegiatan belajar yang sedang berlangsung. Salkind (2008: 687) memaknai motivasi sebagai arah atau petunjuk serta energi penggerak dari suatu tingkah laku. Motivasi berfungsi menimbulkan, mendasari, mengarahkan suatu perbuatan, dan motivasi juga dapat menentukan baik tidaknya dalam mencapai tujuan, sehingga semakin besar motivasinya akan semakin besar pula kesuksesannya (Ahmadi dan Suprayono, 2003:83). Wlodkowsky 
(Prasetya dkk, 1985) mengemukakan bahwa motivasi merupakan suatu kondisi yang menyebabkan atau menimbulkan perilaku tertentu dan yang memberi arah dan ketahanan pada tingkah laku tersebut.

Motivasi belajar siswa beragam, dapattinggi, sedang, dan rendah. Suzanne Hidi; Judith M. Harackiewicz (2007) mengemukakan bahwa motivasi belajar rendah disebabkan oleh pekerjaan atau tugas-tugas sekolah yang terlalu sulit, tuntutan guru dan orang tua yang terlalu tinggi, kegiatan non akademik yang lebih menarik dan menantang. Hamzah B Uno (2008) dan Arden N. Frandsen (Baharudin, 2007) mengemukakan bahwa motivasi belajar dipengaruhi oleh faktor instriksik dan ekstrinsik. Tinggi rendahnya motivasi belajar siswa berdampak pada proses dan hasil belajar. Untuk itu, perlu kiranya adanya upaya untuk meningkatkan motivasi belajar, agar proses dan hasil belajar dapat dicapai secara optimal. Permalasahan motivasi belajar dirasakan sebagai suatu permasalahan dalam pendidikan, namun diyakini bahwa dapat diselesaikan. Perubahan motivasi belajar dapat terjadi manakala terdapat stimulus yang disiapkan dan adanya respons positif dari siswa.

Pemahaman secara mendalam tentang diri siswa dapat membantu ketepatan dalam memberikan bantuan, semakin mendalam pemahaman terhadap diri siswa maka akan semakin tepat bantuan diberikan. Bimbingan dan konseling merupakan suatu proses pemberian bantuan secara ilmiah, memiliki pendekatan, teknik dan strategi serta bidang layanan untuk membantu siswa mencapai kemandirian dalam kehidupannya. Salah satu strategi bimbingan dan konseling adalah bombingan klasikal (PMPTK, 2007). Menurut Geltner dan Clark (2005) bimbingan klasikal (classroom guidance) merupakan bagian yang penting diberikan dalam kurikulum bimbingan, yaitu sekitar 25\% sampai dengan 35\%. Layanan bimbingan klasikal merupakan cara yang paling efektif dalam mengidentifikasi siswa yang membutuhkan perhatian ekstra (Myrick, 2003; Geltner dan Clark, 2005). Dalam kaitannya dengan pengertian bimbingan klasikal, Gysber \& Henderson (1998) menyatakan bahwa bimbingan klasikal merupakan bentuk kegiatan yang diselenggarakan dalam guidance curriculum. Meskipun kurikulum bimbingan merupakan inti dari kegiatan layanan, namun hanya terdapat $24 \%$ studi yang dilakukan pada area ini. Review terhadap 12 hasil studi yang dilakukan oleh Whiston \& Sexton tentang bimbingan klasikal menunjukkan bahwa: delapan studi yang meneliti tentang keberhasilan bimbingan klasikal dalam meningkatkan harga diri (self esteem) dan konsep diri (self concept). Satu dari dua belas penelitian tersebut menunjukkan keefektifan bimbingan klasikal (Gerler \& Anderson, 1986; Lapan, Gysbers, Hugley \& Arni, 1993; Akos, 2007), dan dua studi diketahui secara spesifik yang meneliti tentang bimbingan klasikal di Sekolah Menengah Atas dan satu studi di Sekolah Menengah Pertama. Bimbingan klasikal merupakan cara yang efektif bagi guru bimbingan dan konseling atau konselor dalam memberikan informasi dan atau orientasi kepada siswa tentang program 
layanan yang ada di sekolah, program pendidikan lanjutan, keterampilan belajar, selain itu layanan bimbingan klasikal dapat digunakan sebagai layanan preventif (Committee for Children, 1992; Akos, 2007). Bimbingan klasikal merupakan bagian yang memiliki porsi terbesar dalam layanan Bimbingan dan Konseling, serta merupakan layanan yang efisien, terutama dalam menangani masalah rasio jumlah konseli dan konselor.

Ruang lingkup layanan bimbingan klasikal dapat meliputi belajar, pribadi, sosial, dan karir. Dalam layanan bimbingan klasikal akan terjadi hubungan timbal balik antara guru bimbingan dan konseling atau konseling dengan siswa atau konseli. Hubungan timbal balik diharapkan terjadinya interaksi edukatif dalam arti mengandung makna mendidik dan membimbing. Hal tersebut menjadi fakta dan gambaran yang menarik untuk melakukan penelitian lebih lanjut dalam kaitannya peningkatan salah satu faktor yang mempengaruhi suatu aktivitas belajar siswa yaitu motivasi belajar. Kaitannya dengan layanan bimbingan belajar, terdapat beberapa data pendukung lain yang diperoleh oleh peneliti dalam studi pendahuluan. Mulyani (2003) dalam penelitiannya menunjukkan bahwa terdapat hubungan yang positif dan signifikan antara layanan informasi bimbingan belajar dengan minat belajar, dalam arti bahwa semakin tinggi layanan bimbingan belajar yang diberikan maka semakin tinggi minat belajar siswa. Sumartono (2003), dalam penelitiannya menunjukkan bahwa semakin efektif layanan bimbingan kelompok belajar yang diberikan, maka akan semakin tinggi motivasi belajar para siswa.

Paparan tersebut memberikan dukungan perlu adanya pengembangan model layanan bimbingan klasikal untuk meningkatkan motivasi belajar siswa yang efektif dan efisien. Hal ini mengingat bahwa rasio jumlah siswa dibanding guru bimbingan dan konseling atau Konselor pada satuan pendidikan 1:150. Studi pendahuluan menunjukkan bahwa rasio guru bimbingan dan konseling : siswa / konseli $=1$ : 180, sedangkan idealnya $1: 100$. Bila layanan individual diterapkan bagi semua siswa, maka memerlukan waktu sangat lama untuk memberikan setiap siswa, bahkan selama satu semester belum tentu semua siswa mendapat sentuhan dari Guru Bimbingan dan Konseling secara penuh.

Atas dasar paparan tersebut diatas, secara umum permasalahan pokok yang ingin dijawab melalui penelitian ini adalah "Bagaimanakah model bimbingan klasikal yang dapat meningkatkan motivasi belajar siswa SMP Negeri di Kulon Progo Daerah Istimewa Yogyakarta?" dan "Seberapa besar efektivitas model bimbingan klasikal yang dapat meningkatkan motivasi belajar siswa SMP Negeri di Kulon Progo Daerah Istimewa Yogyakarta?"

\section{METODE}

Penelitian ini menggunakan pendekatan Research \& Development. Borg \& Gall, (1983) mengemukakan bahwa $R e-$ search \& Development digunakan dalam pengembangan dan validasi suatu produk atau model pendidikan. Tahap- 
tahap penelitian Research \& Development sebagaimana dikemukakan oleh Sukmadinata (2010) meliputi (1) studi pendahuluan; (2) pengembangan model; dan (3) uji model. Subjek penelitian ini adalah siswa SMP dan Guru bimbingan dan konseling di Kulon Progo Yogyakarta, dengan teknik pengambilan sampel purposive random sampling. Teknik pengumpulan data yang digunakan adalah angket untuk mengumpulkan pelaksanaan bimbingan klasikal di sekolah dan motivasi belajar siswa. Data tersebut dianalisis secara deskriptif-naratif untuk memperoleh pemahaman terhadap hasil studi pendahuluan, pengembangan dan validasi model. Efektivitas model bimbingan klasikal untuk meningkatkan motivasi belajar siswa SMP dilakukan uji perbedaan rata-rata, yaitu uji-t (t-test).

\section{Tahap 1 : Studi Pendahuluan}

Pada tahapan ini peneliti melakukan assesmen kebutuhan dengan cara melakukan studi pustaka untuk menelaah konsep bimbingan klasikal dan motivasi belajar, dan menyusun instrumen pengumpulan data tentang pelaksanaan bimbingan klasikal dan motivasi belajar siswa. Kajian faktor-faktor yang mempengaruhi motivasi belajar siswa dilakukan sebagai dasar dalam pengembangan instrumen motivasi belajar. Dalam bimbingan klasikal dikaji tentang unsurunsur dalam pelaksanaan bimbingan klasikal. Informasi penelitian diperoleh dari 8 SMP di kabupaten Kulon Progo.

\section{Tahap II : Pengembangan Model}

Pada tahapan ini peneliti menyusun rancangan model hipotetik dan pandu- an bimbingan klasikal untuk meningkatkan motivasi belajar siswa Sekolah Menengah Pertama di Kabupaten Kulon Progo. Berdasarkan kajian teoretis dan analisis data empiris tentang bimbingan klasikal dan motivasi belajar, maka dirumuskan model dan panduan operasional bimbingan klasikal untuk meningkatkan motivasi belajar siswa. Sajian model meliputi rasional, tujuan, kompetensi konselor, langkah-langkah, evaluasi dan indikator keberhasilan, struktur dan isi intervensi. Sedangkan panduan berisi komponen model ditambah materi intervensi yang disajikan dalam bentuk satuan layanan bimbingan klasikal yang meliputi: bidang layanan, pokok bahasan, materi, tujuan, fungsi, subjek, waktu, jam, kegiatan konselor, kegiatan siswa, metode, alat/ media, evaluasi, dan uraian pokok materi.

Sebagai langkah lanjut pada tahapan ini adalah dilakukan pengujian rasional kelayakan model oleh pakar dan uji keterbacaan oleh guru bimbingan dan konseling dalam bentuk focus group discussion. Pada tahap ini dikaji pula tentang desain model dan rancangan implementasi pelaksanaan, dan diakhiri dengan evaluasi dan refleksi untuk memperoleh umpan balik yang dipergunakan untuk melakukan revisi.

\section{Tahap III : Validasi Model}

Pada tahapan ini, peneliti melakukan uji efektivitas model dengan menggunakan metode kuasi eksperimen pola pretest posttest (McMillan \& Schumacher, 2001:330). Uji efektivitas model dilakukan pretest tentang motivasi belajar siswa, baik pada kelompok eksperimen 
maupun kelompok kontrol, dilanjutkan treatment/intervensi menggunakan strategi bimbingan klasikal dengan materi motivasi belajar dan diakhiri posttest. Uji efektivitas dilakukan dengan cara membandingkan rerata skor motivasi belajar antara pretest dengan posttest dalam kelompok eksperimen, membandingkan rerata skor motivasi belajar antara pretest dengan posttest dalam kelompok kontrol, dan membandingkan rerata skor motivasi belajar antara pretest dengan posttest dalam kelompok eksperimen dan kelompok kontrol. Hasil uji efektivitas merupakan dasar untuk validasi model dalam merumuskan atau merekomendasi model akhir yang telah teruji.

\section{HASIL}

\section{Gambaran Layanan Bimbingan Klasi- kal di SMP di Kulon Progo}

Pelaksanaan bimbingan klasikal pada SMP di Kulon Progo dapat disajikan sebagai berikut.

- Pelaksanaan diketahui 50\% Guru BK selalu memberikan bimbingan klasikal, 15\% hampir selalu, 20\% kadangkadang, 5\% hampir tidak pernah, dan $5 \%$ tidak pernah.

- Jadwal pemberian bimbingan klasikal adalah $60 \%$ selalu sesuai jadwal, $20 \%$ hampir selalu sesuai jadwal, dan $15 \%$ kadang-kadang sesuai jadwal.

- Materi layanan diketahui sebanyak $65 \%$ Guru BK selalu menyusun satuan layanan sebelum memberi layanan Bimbingan klasikal, 20\% guru yang hampir selalu dan $15 \%$ guru yang kadang-kadang menyusun satuan layanan. Materi disusun ber- dasarkan hasil need assesment oleh guru diketahui sebanyak $40 \%$ guru, $20 \%$ hampir selalu, dan $40 \%$ yang lain masuk dalam kategori kadangkadang.

- Dalam menyusun satuan layanan berdasarkan Standar Kompetensi Kemandirian Siswa, sejumlah 60\% guru (15\% hampir selalu dan 25\% kadangkadanng), atas dasar keinginan sendiri (25\% selalu, 10\% hampir selalu, 25\% kadang-kadang dan hampir tidak pernah, serta 15\% tidak pernah), atas dasar kajian teori diketahui (30\% selalu, 55\% hampir selalu, 5\% hampir tidak pernah, dan 5\% yang lain tidak pernah).

- Kegiatan layanan Bimbingan klasikal yang dilakukan oleh Guru BK sudah diawali dengan perumusan tujuan $(85 \%)$, sementara $10 \%$ (hampir selalu) masih belum secara utuh melakukan perumusan tujuan.

- Metode layanan bimbingan klasikal yang digunakan oleh Guru BK SMP di Kulon Progo adalah tanya jawab $(30 \%)$, diskusi $(25 \%)$, curah gagasan (10\%) dan analisis film (5\%). Penggunaan media sejumlah $10 \%$ guru yang tidak menggunakan media, dan 90\% telah menggunakan bantuan media.

- Pelaksanaan evaluasi terhadap bimbingan klasikal diketahui 55\% Guru BK selalu melakukan evaluasi, 20\% hampir selalu, 15\% kadang-kadang dan 5\% hampir tidak pernah.

- Pada tindak lanjut proses layanan berdasarkan hasil evaluasi layanan bimbingan klasikal diketahui 55\% Guru BK selalu melakukannya, selebihnya 
$25 \%$ hampir selalu, 5\% kadang-kadang dan $5 \%$ hampir tidak pernah.

\section{Gambaran Motivasi Belajar Siswa SMP di Kabupaten Kulonprogo}

Instrumen yang digunakan untuk mengukur motivasi belajar adalah skala jawaban 1-5, sejumlah 30 item untuk faktor intrinsik dan 32 item faktor eks- trinsik. Secara hipotetik instrumen ini memberikan skor hasil pengukuran motivasi belajar faktor intrinsik antara 30-150, motivasi belajar faktor ekstrinsik antara 32-160, dan total antara 62310. Klasifikasi skore dibagi menjadi 5 yaitu sangat tinggi, tinggi, sedang, rendah dan sangat rendah, dan kondisi motivasi belajar siswa sebagai berikut.

Tabel 1. Sebaran Motivasi Belajar Siswa SMP di Kulon Progo Yogyakarta

\begin{tabular}{lcccccc}
\hline \multirow{2}{*}{ Klasifikasi } & \multicolumn{2}{c}{ Instrinsik } & \multicolumn{2}{c}{ Ekstrinsik } & \multicolumn{2}{c}{ Motivasi } \\
\cline { 2 - 7 } & Frek & Persen & Frek & Persen & Frek & Persen \\
\hline Sangat Rendah & 2 & 0.2 & 1 & 0.1 & 0 & 0 \\
Rendah & 11 & 0.9 & 154 & 12.4 & 31 & 2.5 \\
Sedang & 165 & 13.3 & 663 & 53.3 & 388 & 31.2 \\
Tinggi & 594 & 47.7 & 378 & 30.4 & 722 & 58.0 \\
Sangat Tinggi & 472 & 37.9 & 48 & 3.9 & 103 & 8.3 \\
Total & 1244 & 100 & 1244 & 100 & 1244 & 100 \\
\hline
\end{tabular}

Sumber : Hasil pengolahan data primer

\section{Pengembangan Model}

Tujuan akhir penelitian ini adalah terumuskannya model bimbingan klasikal untuk meningkatkan motivasi belajar siswa di Sekolah Menengah Pertama Kabupaten Kulon Progo. Perumusannya didasarkan kajian teori dan hasil penelitian, pengalaman proses pemberian layanan yang dilakukan oleh Guru Bimbingan dan Konseling, serta penelitian lapangan yang dilakukan melalui desain penelitian quasi eksperimen.

Model Hipotetik Bimbingan Klasikal untuk Meningkatkan Motivasi Belajar Siswa SMP di Kulon Progo Yogyakarta

Bimbingan klasikal merupakan layanan yang bersifat preventive, curative, preservative, dan developmental dan me- rupakan cara yang efisien dalam memberikan informasi kepada siswa sejumlah satuan kelas. Rasio guru bimbingan dan konseling dengan siswa di Indonesia terkategori berjumlah besar, sebagaimana dinyatakan dalam PP 74/ 2008 tentang Guru bahwa jumlah peserta didik yang menjadi tanggung jawabnya adalah minimal 150 peserta didik per tahun. Dalam kaitan rasio ini, menurut (Myrick, 2002; Schmidt, 2008; Bringman \& Lee, 2008), bimbingan klasikal merupakan jawaban atas adanya rasio konselor dengan siswa yang sangat besar, layanan bimbingan klasikal merupakan layanan yang efektif dan efisien untuk meningkatkan kebutuhan dari peserta didik di sekolah.

Bimbingan klasikal terfokus pada pemenuhan tugas siswa yang spesifik pada domain kognitif, afektif, dan psi- 
komotor. Bloom (Englehart, Frost, Hill \& Krathwohl (1956; Cobia, 2007), mengemukakan bahwa pada domain kognitif bimbingan klasikal diarahkan pada konsep, fakta, hasil intelektual. Domain kognitif meliputi kategori pencapaian pengetahuan, transfer informasi, aplikasi, analisis, sintesis dan evaluasi. Menurut Krathwohl, Bloom, \& Masia (1964) dan Cobia (2007) pada domain afektif diarahkan pada sikap dan perasaan. Sedangkan pada domain psikomomotor menurut Gunter, Estes, dan Schwab (2003); Cobia (2007) diarahkan pada keterlibatan kemampuan dan koordinasi tubuh yang baik.

\section{Struktur Model Bimbingan Klasikal untuk Meningkatkan Motivasi Belajar}

Siswa SMP meliputi rasional, tujuan, kompetensi guru bimbingan dan konseling dan langkah-langkah.

\section{- Rasional}

Siswa pada dasarnya memiliki potensi untuk berkembang optimal sesuai potensi yang dimiliki dan pendidikan yang diperoleh. Siswa sebagai makhluk individu tidak terlepas dari lingkungan sosialnya, dan akan berkembang sesuai dengan kondisi lingkungannya. Dalam penyelenggaraan pendidikan di kelas, siswa dapat saling beriteraksi yang berdampak terhadap perkembangan masing-masing siswa. Menurut Schunk \& Pajares (2005) dan Clanton Harpine (2008) individu merupakan produk dari suatu lingkungan, tetapi mereka juga menciptakan dan menginterpretasikan pengalaman lingkungan mereka dengan cara belajar. Sternberg (2000) Harpine( 2008)mengemukakan bahwa individu pada hakikatnya memiliki hasrat untuk belajar.

Proses dan hasil belajar individu dipengaruhi oleh banyak faktor, salah satu faktor dalam kaitan penelitian ini adalah motivasi belajar. Hasil penelitian Sigit Setyawan (2002) menunjukan adanya korelasi yang positif siginifikan antara motivasi belajar dengan prestasi belajar dan antara layanan bimbingan belajar dengan motivasi belajar. Hal yang sama adalah yang dilakukan oleh Wahyudi Suhartono (2003) bahwa terdapat hubungan yang positif antara bimbingan kelompok dengan motivasi belajar. Noor Fajri Yulianti (2008) menemukan bahwa motivasi belajar pada siswa SMP dapat ditingkatkan melalui konseling kelompok.

Gysber \& Henderson (1998) menyatakan bahwa bimbingan klasikal merupakan bentuk kegiatan yang diselenggarakandalam guidancecurriculum yang merupakan jantung dari layanan bimbingan dan konseling. Berdasarkan ModelASCA (2005), bimbingan klasikal merupakan bentuk kegiatan yang diselenggarakan dalam layanan dasar (guidance curriculum). Komponen layanan dasar bersifat developmental, sistematik, terstruktur, dan disusun untuk meningkatkan kompetensi sosial, pribadi, belajar dan karir individu. Layanan Dasar merupakan layanan yang terstruktur untuk semua siswa sampai kelas tiga SLTA, disajikan melalui kegiatan kelas atau kelompok untuk membahas kebutuhan perkembangan dalam bidang akademik, karir, dan pribadi sosial siswa. Alokasi waktu yang disediakan untuk penyelenggaraan dari seluruh program bimbingan dan konseling 
di sekolah $20-30 \%$ untuk SLTP. Bimbingan klasikal efektif dan efisien dalam layanan yang bersifat pencegahan, penyembuhan, perbaikan, pemeliharaan dan pengembangan siswa. Materi layanannya dapat meliputi bimbingan pribadi, sosial, belajar dan karir, salah satu materi bimbingan belajar adalah tentang motivasi belajar, yang mempunyai arti penting dalam proses dan hasil belajar siswa. Motivasi belajar merupakan penggerak, pendorong, dan pengarah siswa dalam melakukan aktivitas belajar untuk mencapai tujuan belajar.

\section{- Tujuan}

Tujuan yang ingin dicapai adalah merumuskan model bimbingan klasikal untuk meningkatkan motivasi belajar siswa SMP di Kulon Progo Yogyakarta.

\section{- Kompetensi Konselor}

Secara umum, kompetensi yang harus dimiliki guru bimbingan dan konseling adalah kompetensi akademik dan profesioal sebagaimana yang tertuang dalam Permendiknas Nomor 27 Tahun 2008 tentang Standar Kualifikasi Akademik dan Kompetensi Konselor (Depdiknas, 2008), dan secara khusus kompetensi yang harus dimiliki untuk implementasikan model bimbingan klasikal untuk meningkatkan motivasi belajar siswa meliputi (1) memahami konsep motivasi belajar siswa; (2) memahami latar belakang yang mempengaruhi motivasi belajar siswa; (3) mampu membuat rancangan materi bimbingan klasikalyang dapat mempengaruhi motivasi belajar siswa; (4) menguasasi materi bimbingan klasikal untuk meningkatkan motivasi belajar siswa; (5) mam- pu menggunakan berbagai macam metode dalam melakukan bimbingan klasikal untuk meningkatkan motivasi belajar siswa; (6) mampu melakukan evaluasi proses dan hasil bimbingan klasikal untuk meningkatkan motivasi belajar siswa.

\section{- Langkah-langkah}

Pengembangan model bimbingan klasikal untuk meningkatkan motivasi belajar siswa SMP melalui langkahlangkah sebagai berikut.

- Pengumpulan data, untuk memperoleh gambaran pelaksanaan bimbingan klasikal dan kondisi motivasi belajar siswa.

- Analisis data yang diperoleh dan konseptualisasi atas hasil pengumpulan data menjadi dasar pengembangan model bimbingan klasikal.

- Penyusunan rancangan modelberdasarkan pada data studi empirik dan kajian teori yang relevan. Komponen modelmeliputi rasional, tujuan, kompetensi konselor, langkah-langkah, evaluasi dan indikator keberhasilan, struktur dan isi intervensi, yang merupakan hipotetik model.

- Validasi rasional model oleh ahli dan validasi keterbacaan model oleh Guru BK di sekolah yang berlatar belakang pendidikan S-1 BK.

- Validasi empirik model kepada siswa, berupa pemberian intervensi secara klasikal berupa 8 pokok bahasan.

- Pelaksanaan bimbingan klasikal untuk meningkatkan motivasi belajar siswa SMP berlangsung 10 kali pertemuan yaitu pretest, dilanjutkan 8 materi intervensi tentang: Keinginan Berprestasi, Kebutuhan/ Kewajiban 
Belajar, Kesadaran Belajar sebagai Kunci Kesuksesan, Belajar untuk Meraih Harapan dan Cita-Cita Masa Depan, Kesenangan Belajar, Keinginan terhadap penguasaan materi, keuletan dalam mengerjakan tugas, Ketekunan belajar, dan diakhiri dengan posttest.

\section{Evaluasi dan Indikator Keberhasilan}

Evaluasi terhadap intervensi dilakukan pada setiap pertemuan dan setelah seluruh pertemuan bimbingan klasikal selesai. Hasil evaluasi dipergunakan untuk perbaikan proses dan tolok ukur keberhasilan bimbingan klasikal untuk meningkatkan motivasi belajar siswa SMP.

Indikator keberhasilan model bimbingan klasikal adalah secara keseluruhan adalah meningkatnya motivasi belajar siswa, dan secara rinci terjadinya peningkatan kadar motivasi belajar siswa setiap indikator instriksik yang meliputi peningkatan (1) keinginan berprestasi; (2) pemahaman siswa tentang kewajiban belajar; (3) kesadaran belajar; (4) pengetahuan dan pemahaman siswa tentang harapan serta cita-cita di masa depan; (5) kesenangan belajar dan mampu mengimplementasikannya dalam kehidupan sehari-hari; (6) keinginan penguasaan materi; 7) keuletan dalam mengerjakan tugas siswa, dan 8) ketekunan belajar.

\section{Validasi Rasional Model}

Dalam upaya menghasilkan model bimbingan klasikal yang teruji efektif harus dilakukan dengan mengikuti kaidah metodologi yang ilmiah. Untuk memenuhi maksud tersebut, maka di- lakukan pengujian terhadap kelayakan model. Uji kelayakan model dilakukan melalui penilaian pakar (expert judgement).

\section{Hasil Uji Lapangan Model}

Upaya peneliti untuk mengetahui hasil uji coba lapangan model layanan Bimbingan klasikal adalah dengan melakukan uji efektivitas pada SMP di Kulon Progo. Hasil perhitungan efektivitas dan peningkatan bimbingan klasikal untuk meningkatkan motivasi belajar siswa SMP di Kulon Progo menunjukkan bahwa secara keseluruhan meningkat $44,99 \%$, dan setiapindikator.

\section{PEMBAHASAN}

\section{Gambaran Layanan Bimbingan Kla- sikal}

Secara umum Guru Bimbingan dan Konseling di Kulon Progo menyadari pentingnya pemberian bimbingan klasikal. Hal ini sesuai dengan pendapat Myrick (2002), Schmidt (2008) dan Bringman \& Lee (2008) yang menyatakan bahwa bimbingan klasikal merupakan jawaban atas adanya rasio konselor dengan siswa yang sangat besar, layanan bimbingan klasikal merupakan layanan yang efektif dan efisien untuk meningkatkan kebutuhan dari peserta didik di sekolah.

Masalah yang muncul dalam kegiatan bimbingan klasikal di Kabupaten Kulon Progo adalah belum semua sekolah memberikan jadwal melakukan bimbingan klasikal. Data studi pendahuluan menunjukkan bahwa lebih dari 50\% guru bimbingan dan konseling tidak memperoleh kesempatan memberikan bimbingan klasikal. Hal 
ini bertentangan dengan konsep dasar yang diberikan oleh ASCA yang menyatakan bimbingan klasikal merupakan bentuk kegiatan yang diselenggarakan dalam layanan dasar (guidance curriculum). Komponen layanan dasar bersifat developmental, sistematik, terstruktur, dan disusun untuk meningkatkan kompetensi sosial/pribadi, belajar dan karir. Pada model ASCA tersebut bahwa persentase penyelenggaraan bimbingan klasikal yang identik dengan layanan dasar (guidance curriculum) untuk SLTP adalah sebesar 20$30 \%$. Atas dasar ASCA maka perlu penataan jadwal pendidikan di sekolah terkait dengan bimbingan klasikal.

Proses need assesment sebagai kegiatan utama pelaksanaan Bimbingan klasikal belum menjadi prioritas guru bimbingan dan Konseling. Hal ini berbeda dengan pendapat yang diberikan oleh Fall (1994; Akos; Cockman; Strickland, 2007) mengenai proses bimbingan klasikal. Menurut Fall dalam proses layanan bimbingan klasikal terdapat tahapan yang spesifik dapat diikuti, yaitu: menentukan tujuan, melakukan pra-assesment, membuat program yang objective dan konkret, membuat desain aktivitas instruksional, dan melakukan evaluasi. Selain itu, layanan Bimbingan Klasikaldapat diberikan melalui beberapa cara.

Upaya penyusunan materi layanan Bimbingan klasikal yang dilakukan oleh guru bimbingan dan konseling di Kulon Progo diketahui banyak berdasarkan kajian teori, mengambil materi dari buku-buku yang telah ada. Hal ini akan menjadi lebih baik apabila dilakukan diskusi bersama guru mata pelajaran yang juga selalu bertatap muka dengan siswa.

Metode bimbingan klasikal yang sering digunakan oleh guru bimbingan dan konseling di SMP Kulon Progo adalah tanya jawab dan menggunakan media. Menurut Woolfolk (1998) dan Cobia (2007) mengemukakan bahwa konselor dapat menggunakan metode lain adalah bertanya, resitasi, pemberian tugas rumah, dan menggunakan praktik yang tersupervisi dan pendekatannya berpusat kepada siswa.

Pelaksanaan evaluasi terhadap proses bimbingan dan konseling selalu dilakukan oleh Guru BK. Evaluasi yang digunakan oleh Guru BK atau Konselor di kabupaten Kulon Progo masih belum secara spesifik menunjukkan tipe atau model. Menurut Badrujaman (2009), salah satu proses evaluasi yang dapat dilakukan adalah menggunakan model CIPP (Contex, Input, Process, Product).

\section{Gambaran Motivasi Belajar}

Motivasi belajar pada siswa di Kabupaten Kulon Progo motivasi termasuk dalam klasifikasi tinggi dimana motivasi instrinsik lebih besar dibandingkan ekstrinsik. Rata-rata tersebut menjelaskan motivasi belajar siswa secara keseluruhan. Sedangkan secara individu menunjukkan tidak semuanya dalam tingkat sedang dan tinggi, namun ditemukan juga beberapa siswa dengan tingkat motivasi belajar sangat rendah, rendah dan sangat tinggi. Dengan demikian meskipun secara mayoritas siswa SMP di Kabupaten Kulon Progo sudah memiliki motivasi belajar intrinsik yang tinggi, namun masih ada 
sebagian yang masih memerlukan bantuan karena motivasi belajarnya masih rendah dan yang sudah tinggi juga perlu layanan pemeliharaan. Sternberg (2000) dan Clanton Harpine (2008) mengemukakan bahwa pada dasarnya seorang anak terlahir dengan memiliki motivasi untuk belajar. Hal ini sejalan dengan pemikiran Baker (2000) dan Clanton Harpine (2008) seorang anak akan mencapai kesuksesan apabila memiliki hasrat untuk belajar.

\section{Hasil Akhir Model Bimbingan Kla- sikal untuk Meningkatkan Motivasi Belajar Siswa SMP di Kulon Progo Yogyakarta}

Hasil analisis uji efektivitas menunjukkan bahwa terbukti efektif, dengan demikian model hipotetik dapat diterima sebagai model bimbingan klasikal untuk meningkatkan motivasi belajar siswa SMP di Kulon Progo Yogyakarta. Komponen subtansi model bimbingan klasikal untuk meningkatkan motivasi belajar siswa SMP meliputi : rasional, tujuan, kompetensi konselor, langkah-langkah, evaluasi dan indikator keberhasilan, dan target intervensi. Komponen suplemen/panduan pelaksanaan bimbingan klasikal untuk meningkatkan motivasi belajar siswa SMP meliputi komponen model ditambah struktur dan isi intervensi yang disusun dalam bentuk satuan layanan bimbingan dan konseling. Isi dalam satuan layanan bimbingan dan konseling meliputi bidang gerak, pokok bahasan, materi layanan, tujuan layanan, fungsi layanan, subyek layanan, waktu, jam, kegiatan Guru BK, kegiatan siswa/kon- seli, metode, alat/media, evaluasi, dan uraian pokok materi.

\section{PENUTUP}

Berdasarkan keseluruhan proses pengembangan Model Bimbingan Klasikal untuk meningkatkan motivasi belajar siswa dapat ditarik beberapa kesimpulan sebagai berikut.

- Model hipotetik bimbingan klasikal untuk meningkatkan motivasi belajar siswa yang dikembangkan terdiri dari dua bagian, yaitu substansi model dan suplemen model. Aspek substansi model berisi rumusan tentang rasional, tujuan, asumsi, komponen, kompetensi, struktur intervensi atau langkah-langkah, evaluasi dan indikator keberhasilan. Aspek suplemen model lebih bersifat teknis-operasional yang berisi rumusan tentang deskripsi model, peran konselor, dan adegan layanan yang tertuang dalam satuan layanan bimbingan klasikal.

- Hasil validasi rasional pakar bimbingan dan konseling terhadap model hipotetik layanan bimbingan klasikal untuk meningkatkan motivasi belajar siswa menunjukkan bahwa model yang dikembangkan dinilai layak sebagai suatu model intervensi.

- Model bimbingan klasikal secara empirik terbukti efektif untuk meningkatkan 8 indikator motivasi intrinsik. Setelah diberikan treatmen dengan materi yang disusun dalam satuan layanan sejumlah 8 pokok bahasan dan dilaksanakan dalam setting kelas menunjukkan adanya peningkatan yang signifikan setiap indikator motivasi belajar. 
- Peningkatan kadar motivasi belajar secara keseluruhan setelah diberikan treatmen secara keseluruhan sebesar $44,9 \%$.

- Bimbingan klasikal yang dikembangkan untuk meningkatkan motivasi belajar siswa di Kabupaten Kulon Progo, berdasarkan studi pustaka dan empirik dapat dijadikan sebagai salah satu model dalam layanan bimbingan dan konseling.

\section{UCAPAN TERIMA KASIH}

Ucapan terima kasih disampaikan kepada semua pihak yang telah membantu terselenggaranya penelitian ini, khususnya para guru dan siswa SMP di Kabupaten Kulon Progo yang telah bersedia menjadi subjek/sumber data penelitian. Semoga jasa dan bantuannya selama ini diperhitungkan sebagai amal ibadah.

\section{DAFTAR PUSTAKA}

Akos, Patrick, Caroline R Cockman, \& Cindy A Strickland. 2007. “Differentiating Classroom Guidance Professional School Counseling", ProQuest Education Journals, 10, 5, hlm. 455.

Ahmadi, Abu dan Widodo Supriyono. 2003. Pskologi Belajar (edisi revisi). Jakarta: Rineka Cipta.

Baharuddin dan Wahyuni, Esa Nur. 2007. Teori Belajar dan Pembelajaran. Yogyakarta: Ar-ruzz Media Group.

Borg, W. R. \& Gall, M.D. 1989. Educational Research: an Introduction. Fifth Edition. New York: Longman.
Christopher A.Sink, Patrick Akos, Rebecca J.Turnbull, Nyaradzo Mvududu. 2008. An Investigation of Comprehensive School Counseling Programs and Academic Achievement in Washington State Middle Schools. ProQuest Education Journals.

Cobia, D.C. and Henderson, D.H. 2007. Developing an Effective and Accountable School Counseling Program (2e). Cincinnati: Merrill Publishing.

Dirjen PMPTKT.2007. Rambu-rambu Penyelenggaraan Layanan Bimbingan dan Konseling dalam Jalur Pendidikan Formal, Jakarta, Depdiknas.

Depdiknas.2008. Permendiknas No. 27 Tahun 2008, Standar Kualifikasi Akademik dan Kompetensi Konselor, Jakarta.

Gerler, Edwin R Jr, Anderson, Ronald F. 1986. "The Effects of Classroom Guidance on Children's Success in School", Journal of Counseling and Development : JCD. Alexandria. Vol. 65, Iss. 2, hlm. 78.

Gysbers, Norman C and Henderson. 2005. Developing And Managing Your School Guidance and Counseling Program fourth Edition. ACA. USA.

Hamzah B.Uno, 2008, Teori Motivasi dan Pengukurannya, Analisis di Bidang Pendidikan, Jakarta, Bumi Aksara. 
Harpine, E. Clanton. 2008. Group Interventions in Schools. Springer Science Business Media.

Ibrahim. 1996. Inovasi Pendidikan. Jakarta:Depdikbud Dirjendikti Proyek Pengembangan Lembaga Pendidikan Tenaga Kependidikan.

Linda D. Webb dan Greg A Brigman. 2006. "Student Success Skills: Tools and Strategies for Improved Academic and Social Outcomes. Professional School Counseling", ProQuest Education Journals, 10, 2, hlm. 112.

McMillan, J.H. \& Schumacher, S. 2001. Research in Education. A Conceptual Introduction. Fifth Edition. New York: Longman.

Muhibbinsyah. 1997. Psikologi Pendidikan dengan Pendekatan Baru. Bandung: PT Remaja Rosdakarya.

Myrick, R.D. 1993. Developmental Guidance and Counseling: A Practical Approach Second Edition. Minneapolis: Educational Media Corporation.

Nana Syaodih, S. 2007. Bimbingan $\mathcal{E}$ Konseling dalam Praktek. Mengembangkan Potensi dan Kepribadian Siswa. Bandung: Maestro.

2010. Metode Penelitian Pendidikan. Bandung: PT. Remaja Rosdakarya Offset.
Salkind, Neil J. 2008. Encyclopedia of Educational Psychology. Sage Publications, Inc.

Santrock and Yussen. 1997. Life Span Development. Madosin: Brown and Benchmark.

Schunk, Dale H. and Paul R. Pintrich, 2010. Motivation in Education: Theory, Research, and Applications. Merrill.

Steinberg L, 2002, Adolescence. New York: McGraw-Hll Inc.

Suzanne Hidi; Judith M Harackiewicz. Motivating the Academically Unmotivated: A critical issue for the 21st century. Review of Educational Research; Summer 2000; 70, 2; ProQuest Education Journals. pg. 151

Tukija. 2006. Hubungan Antara Motivasi Belajar dengan Prestasi Belajar Siswa Kelas VI Sekolah Dasar SeGugus II Kecamatan Samigaluh Tahun Pelajaran 2005/2006. Tugas Akhir. UNY. Tidak diterbitkan.

Undang-undang No. 20 tahun 2003. Sistem Pendidikan Nasional. Jakarta: Depdikbud.

Yuliani, Noor Fajri. 2008. Upaya Peningkatan Motivasi Belajar melalui Konseling Kelompok Pada Siswa Kelas VIII SMP Negeri 15 Yogyakarta. Tugas Akhir. UNY. Tidak diterbitkan. 